\title{
Traumatized Reptiles: A Retrospective Study of Wild Reptiles Examined in Northeastern Brazil
}

\section{Roberta da Rocha Braga ${ }^{1 *}$ and Antônio Rafael Lima Ramos ${ }^{1,2}$}

${ }^{1}$ Academic Laboratory of Wildlife Pathology (LAPS), Ophiology Department (NUROF), Federal University of Ceará (UFC), Brazil

${ }^{2}$ Systematic, Biodiversity Use and Conservation Post Graduation Program, Federal

University of Ceará (UFC), Brazil

*Corresponding Author: Roberta da Rocha Braga, Academic Laboratory of Wildlife Pathology (LAPS), Ophiology Department (NUROF), Federal University of Ceará (UFC), Brazil.

DOI: 10.31080/ASVS.2021.03.0218
Received: August 16, 2021

Published: September 20, 2021

(C) All rights are reserved by Roberta da

Rocha Braga and Antônio Rafael Lima

Ramos.

\section{Abstract}

Physical injuries represent one of the main threats to free-living animals, and interactions with humans perform the leading cause of their admission in veterinary care. In the USA, the main causes of physical injuries in reptiles and amphibians were run over, fishing or gardening accidents, and predation by domestic carnivores. Anthropic actions potentially increase the morbidity and mortality in reptiles due to traumatic injuries and can cause populations to be isolated in forest remnants, such as urban parks. Fortaleza is a metropolis in northeastern Brazil, that has progressively lost its vegetation cover due to urbanization processes. However, as the ERA "Matinha do Pici", few urban parks stand out as a hotspot of local fauna conservation. The objective of this work was to report and characterize a sample of traumatized reptiles, received, and examined at LAPS-UFC, in Fortaleza, from 2010 to 2020 . Thirty-four cases were included, mostly lizards from the ERA "Matinha do Pici”, with diverse blunt force lesions, mainly caused by domestic carnivores' predation, run over or human predation.

Keywords: Wildlife; Physical Injuries; Predation; Roadkill; Ceará

\section{Abbreviations}

ERA: Ecological Relevance Area; LAPS: Academic Wildlife Pathology Laboratory.

\section{Introduction}

Physical injuries represent one of the main threats to free-living animals, grouped into three categories: conflicts with other animals, accidents and natural disasters [1]. Interactions with humans perform the leading cause of their admission in veterinary care, and rehabilitation attempts have been recorded in common and widely distributed species [2-4].

A study in the USA showed the main causes of physical injuries in reptiles and amphibians were run over, fishing or gardening ac- cidents, and predation by domestic carnivores [5,6]. Rehabilitation centres recorded therapeutic success and subsequent releasing in 68 to $84 \%$ [5]. However, monitoring and rehabilitation centres are not always available, which predisposes to increase morbidity and mortality of traumatized animals. The taxa involved are varied and depend on the local fauna and the risks of existing trauma [7].

Although urban regions can be attractive to some species of reptiles, most studies indicate adverse effects of these regions on their survival rates [7]. Urbanization produces habitat fragmentation, reduces diversity, and may cause the isolation of reptile populations in forest remnants [8,9], as urban parks. Consequently, these events represent potential risks of traumatic injuries by anthropic actions [6]. 
With more than nine million inhabitants, Ceará is the fourth largest state in the Northeast region of Brazil. Fortaleza is its principal city, considered the most urbanized capital of the northeast region; it is located on the state's northern coast, with an area of $360 \mathrm{~km}^{2}$ and 2.5 million inhabitants [10]. In 1988, the vegetation cover of Fortaleza was $154 \mathrm{~km}^{2}$, composed of a coastal vegetation complex, Atlantic Forest and caatinga. In thirty years, this coverage lost 21\% in area, as population density increased [11]. The ERA "Matinha do Pici" [12] stands out among the conservation units, housing 44 species of native reptiles and amphibians [13]. Thus, forest fragments, transformed into urban parks and conservation units, are essential for preserving local herpetofauna, which still resists the advance of local urbanization [14].

The objective of this work was to report traumatized reptiles, received and examined at the Academic Laboratory of Wild Pathology (LAPS-UFC), in Fortaleza, from 2010 to 2020, characterizing types of traumas and the main species affected.

\section{Materials and Methods}

A retrospective study was conducted in the evaluation records of live or dead animals from 2010 to 2020 . The cases were tabulated according to the year of occurrence, taxon/species, origin, type of examination, classification (according to Ressel and Tremori) $[15,16]$ and causes of injuries. The results were presented as absolute and relative frequencies of occurrence.

\section{Results and Discussion}

Thirty-four cases of injured reptiles were counted, representing $28 \%$ of the total necropsies in the period. The distribution of causes by the taxonomic group is presented in table 1 .

\begin{tabular}{|c|c|c|c|c|}
\hline & \multicolumn{4}{|c|}{ Taxon } \\
\hline Causes of injury & Lacertilia & Serpentes & Chelonia & Total \\
\hline $\begin{array}{c}\text { Predation by carni- } \\
\text { vores }\end{array}$ & 11 & 4 & 1 & 16 \\
\hline Roadkill & 6 & 3 & no & 9 \\
\hline Predation by humans & 4 & 2 & no & 6 \\
\hline Gardening accidents & 1 & 1 & no & 2 \\
\hline Electrocussion & 1 & no & no & 1 \\
\hline Total & 23 & 10 & 1 & 34 \\
\hline
\end{tabular}

Table 1: Causes of injury in reptiles examined between 2010 and 2020 at LAPS-UFC diagnostic service, Brazil.
The cases were diagnosed by external examination (55.8\%), necropsy (38.2\%) and clinical diagnosis (5.8\%).

Most of the reptiles examined (70.5\%) proceeded from the UFC Pici Campus or adjacent regions. The Pici Campus (Figure 1) contains the buildings and academic structure of the Federal University of Ceará, around the conservation unit ERA "Matinha do Pici”, in the western Fortaleza [17]. It is characterized as a remnant forest fragment and acts as a relevant wildlife refuge within the metropolis of Fortaleza.

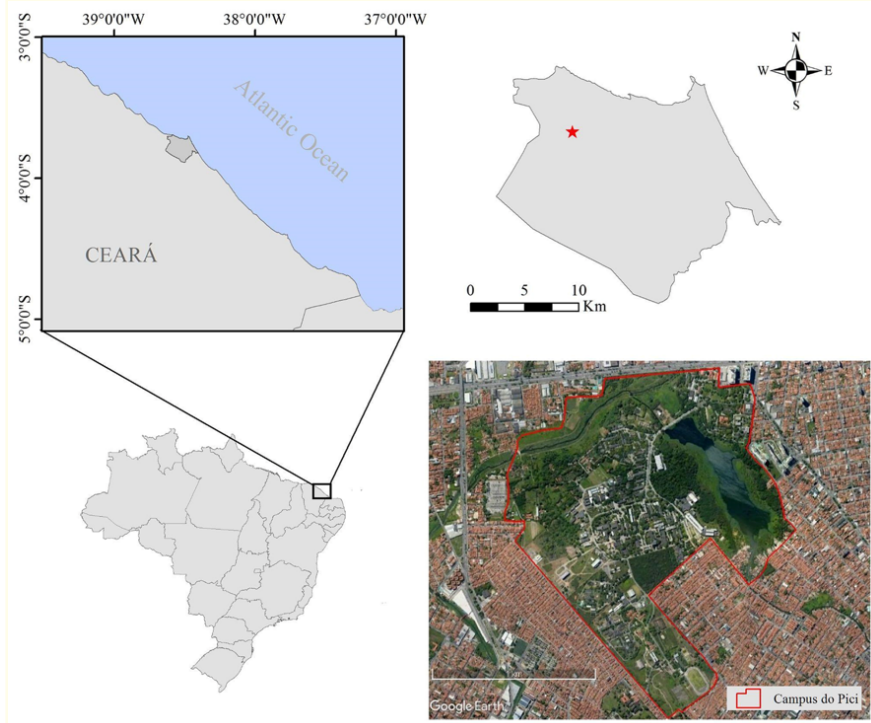

Figure 1: Pici Campus and the ERA "Matinha do Pici", Fortaleza, northeastern Brazil. ArcGis Software, adapted from Google Earth.

In this context, reptiles and other animals constantly conflict with direct and indirect anthropic urban actions. Although management and conservation plans have not been developed to date, factors such as paved roads, abandonment of domestic animals, and humans' regular presence are characterized as potential threats to that fauna $[18,19]$. Even most users are higher education students, which may interact respectfully with herpetofauna [20], irrational fear and revulsion by reptiles frequently make them victims of aggression [21]. In addition, peripheral surrounding communities with a low human development index can integrate another factor of conflicts between wildlife and humans [22]. 
The sample consisted predominantly of lizards (67.6\%), with blunt force lesions due to predation by domestic carnivores (68.7\%). The most affected species were Iguana iguana (20.6\%) from the Pici Campus and Hemidactylus mabouia (20.6\%) from peridomiciliary urban areas. Snakes predated by carnivores $(25 \%)$ had puncture marks compatible with domestic cats' bites, according to the morphometry already described [23]. Researchers [24] estimated that about 478 million reptiles are potentially predisposed to predation by domestic cats in the U.S. annually. The main species and the frequency of their lesions are listed in table 2. Traumatic injuries are described in figure 2.

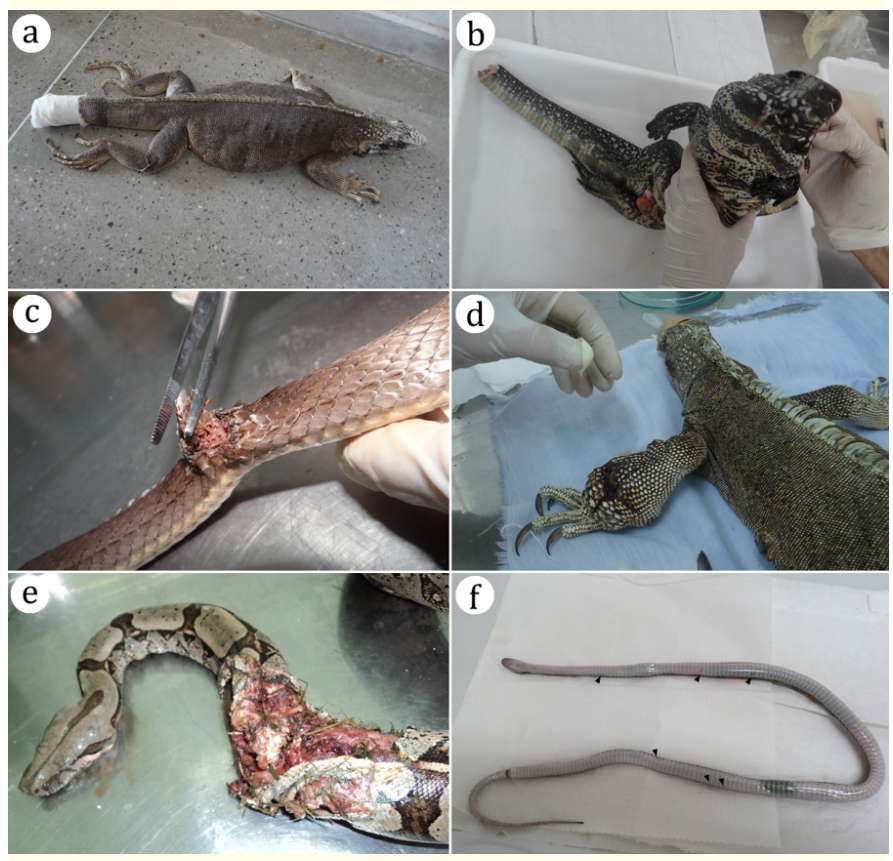

Figure 2: Traumatic injuries in reptiles examined in LAPS-UFC from 2010 to 2020. Road-killed lizards. a) Iguana iguana, alive with fractured tail, and b) Salvator merianae, dead with fractured tail and cloacal prolapse. Blunt force trauma. c) Philodryas nattereri, dead with vertebral fracture and lacerated tissues; d) Iguana iguana, alive with a gangrened laceration in the left anterior limb, and e) Boa constrictor, recently euthanized with extensive laceration by electric grass trimmer. Puncture wounds. f) Oxyrhopus trigeminus, dead with multifocal pairs of puncture wounds in dorsal (not seen) and ventral (black arrowheads) regions.

\begin{tabular}{|c|c|}
\hline Taxon/Species & $\mathbf{R F}$ \\
\hline Lacertilia & $\mathbf{6 7 . 6 \%}$ \\
\hline Hemidactylus mabouia & $20.6 \%$ \\
\hline Iguana iguana & $20.6 \%$ \\
\hline Tropidurus hispidus & $17.6 \%$ \\
\hline Salvator merianae & $8.8 \%$ \\
\hline Serpentes & $\mathbf{2 9 . 4 \%}$ \\
\hline Philodryas olfersii & $11.8 \%$ \\
\hline Philodryas nattereri & $5.9 \%$ \\
\hline Boa constrictor & $5.9 \%$ \\
\hline Helicops leopardinus & $2.9 \%$ \\
\hline Oxyrhopus trigeminus & $2.9 \%$ \\
\hline Chelonia & $\mathbf{2 . 9} \%$ \\
\hline Kinosternon scorpioides & $2.9 \%$ \\
\hline Total & $\mathbf{1 0 0 . 0} \%$ \\
\hline
\end{tabular}

Table 2: Relative frequency (RF) of injured species recorded by LAPS-UFC between 2010 and 2020 .

A recently rescued freshwater turtle from the Pici Campus, kept in captivity for few weeks, was the only examined chelonian. It showed the caudal shell edge and extremities of the limbs with gnawed digits and scar tissue, noting predatory chewing by competition with other turtles in the tank. Territorialism and competition between males result in serious aggressions and can be prevented with fewer individuals inside the enclosures or separated during reproductive seasons [25].

Roadkill was the second leading cause of injury $(27.2 \%)$, followed by predation by humans $(21.2 \%)$. It was observed that the trauma prevalence in reptiles and amphibians increased during the spring and summer months in the central U.S., which corresponded to periods of greater dispersion and confrontations of these animals with humans [5]. As ectothermic organisms, the search for adequate heat sources leads them to lie on the paved roads for thermoregulation [26]. Consequently, this behaviour makes these ectothermic animals vulnerable to trauma from roadkill and crushing caused by motor vehicles and pedestrian traffic $[26,27]$. The impact of motor traffic is strong enough to limit the growth of some chelonians' populations, as they cannot avoid traffic, and their low fertility does not allow equivalent replacement of dead individuals [28]. 
Extensive lacerations are severe injuries due to roadkill, combining bruises and tissue rupture [6]. Predation by humans is reported as a conflict of interaction between men and wild animals. Regarding reptiles, snakes are usually the most affected group due to the perceived risk they offer, while many lizards and amphibians cause revulsion and fear [29]. Blunt force action defines the road-kill inflicted injuries, such as blows and shocks with unsharp instruments [15], in addition to injuries due to hunting, defence or collecting by cultural appeal [30].

One case was diagnosed as "electrocution". In an area of vegetation suppression adjacent to Pici Campus, the event was witnessed by several people, including technicians who tried to contain the Iguana before it reached the machinery electric cables. Injuries included tong bite laceration, thoracic haemorrhages, joint stiffness, and distended heart, with clots. There was one left rib fractured, causing lung perforation, and it was not clear whether due to a manual contention attempt or strong muscle contractions. Congestion was seen in the liver, spleen, lungs and heart. The carcass showed early rigor mortis. Internal lesions associated with electrical injury are usually very subtle unless due to high voltage and prolonged contact. Early rigor mortis was suggestive of high voltage electrical shock [31]. Maybe if nobody had seen the event, the diagnosis could be challenging to determine causes with necropsy only.

\section{Conclusion}

Reptile traumatic injuries accounted for nearly thirty per cent of the LAPS-UFC cases between 2010 and 2020. Lizards were the most affected by roadkill and predation, mainly by domestic cats. The information in this article will contribute to the statistics of damage to urban fauna in general. It will serve locally as subsidies for developing risk mitigation strategies, especially in the ERA "Matinha do Pici".

\section{Acknowledgements}

We thank the NUROF-UFC team for logistical and technical support to LAPS-UFC activities and the Community of Pici Campus, which acts in the voluntary monitoring of occurrences.

\section{Conflict of Interest}

Bibliography

1. Animal Ethics. Physical Injuries in Wild Animals (2020).

2. Grogan A and A Kelly. "A Review of RSPCA Research into Wildlife Rehabilitation". Veterinary Record 172.8 (2013): 211-211.

3. Molina-López Rafael Angel., et al. "Morbidity, Outcomes and Cost-Benefit Analysis of Wildlife Rehabilitation in Catalonia (Spain)". PLOS ONE, edited by Antoni Margalida 12.7 (2017): e0181331.

4. Tribe Andrew and Peter R Brown. "The Role of Wildlife Rescue Groups in the Care and Rehabilitation of Australian Fauna". Human Dimensions of Wildlife 5.2 (2000): 69-85.

5. Hartup Barry K. "Rehabilitation of Native Reptiles and Amphibians in DuPage County, Illinois". Journal of Wildlife Diseases 32.1 (1996): 109-112.

6. Brown JD and Sleeman JM. "Morbidity and mortality of reptiles admitted to the Wildlife Center of Virginia, 1991 to 2000". Journal of Wildlife Diseases 38.4 (2002): 699-705.

7. French SS., et al. "Town and Country Reptiles: A Review of Reptilian Responses to Urbanization". Integrative and Comparative Biology 58.5 (2018): 948-966.

8. McDonnell MJ and Pickett STA. "Ecosystem structure and function along urban-rural gradients: an unexploited opportunity for ecology". Ecology 71 (1990): 1232-1237.

9. Cook RP. "Potential and limitations of herpetofaunal restoration in an urban landscape”. In 'Urban Herpetology'. (Eds J. C. Mitchell, R. E. J. Brown and B. Bartholomew (2008): 465-478. (Society for the Study of Amphibians and Reptiles: Salt Lake City, UT.

10. IBGE. “Ceará”. Informações Demográficas, Territoriais e Socioeconômicas (2021).

11. Cruz Andressa Melany Lima da. Análise da cobertura vegetal, das áreas verdes e dos espaços livres de Fortaleza - Ceará. Dissertação de Mestrado, Programa de Pós-Graduação em Desenvolvimento e Meio Ambiente, Universidade Federal do Ceará (2009).

12. Fortaleza. Lei Municipal $N^{\circ} 10.463$ de 31 de Março de 2016. Dispõe sobre a criação da Área de Relevante Interesse Ecológico - ARIE da Matinha do Pici, e dá outras providências. 
13. NUROF. Coleção Herpetológica da Universidade Federal do Ceará. 2021, www.nurof.ufc.br.

14. Pasquini Bruna Bianchi., et al. "Plano de Manejo Do Parque Estadual Do Cocó. (2020).

15. Ressel L., et al. "Blunt Force Trauma in Veterinary Forensic Pathology". Veterinary Pathology 53.5 (2016): 941-961.

16. Tremori Tália Missen., et al. "Classificação Comparada Das Lesões de Ordem Mecânica Segundo a Traumatologia Forense No Exame de Corpo de Delito Em Animais". Revista Brasileira de Criminalística 7.2 (2018): 20-25.

17. UFC. "Área física” (2021).

18. Mariz AF. Impacto das espécies exóticas invasoras sobre a biodiversidade vegetal: um estudo de caso na unidade de conservação ARIE "Matinha do Pici", Fortaleza-CE. Monografia de graduação em Ciências Ambientais, Universidade Federal do Ceará, Fortaleza, Ceará, Brasil (2019): 91.

19. Guilhon BF. Fauna invisível: monitoramento da fauna atropelada no Campus do Pici. Monografia de graduação em Ciências Biológicas, Universidade Federal do Ceará, Fortaleza, Ceará, Brasil (2019): 30.

20. Moura MR., et al. "O relacionamento entre pessoas e serpentes no leste de Minas Gerais, sudeste do Brasil". Biota Neotropica 10.4 (2010): 133-142.

21. Mitchell JC and Brown REJ. "Urban herpetology: global overview, synthesis, and future directions. In 'Urban Herpetology'”. (Eds J. C. Mitchell, R. E. J. Brown and B. Bartholomew.) (2018): 1-30. (Society for the Study of Amphibians and Reptiles: Salt Lake City, UT.).

22. Teixeira CP., et al. "Evaluating patterns of human-reptile conflicts in an urban environment". Wildlife Research 42 (2015): 570-578.

23. Murmann Denise C., et al. "A Comparison of Animal Jaws and Bite Mark Patterns". Journal of Forensic Sciences 51.4 (2006): 846-860.

24. Loss Scott R., et al. "The Impact of Free-Ranging Domestic Cats on Wildlife of the United States". Nature Communications 4.1 (2013): 1396.

25. Divers Stephen J. "Environmental Diseases and Traumatic Injuries of Reptiles”. MSD Veterinary Manual (2020).
26. Ashley EP and Robinson JT. "Road mortality of amphibians, reptiles and other wildlife on the Long Point Causeway, Lake Erie, Ontario". Canadian Field-naturalist 110 (1996): 403-412.

27. Tanner D and Perry J. "Road effects on abundance and fitness of Galapagos lava lizards (Microlophus albemarlensis)". Journal of Environmental Management 85 (2007): 270-278.

28. Cureton James C and Raelynn Deaton. "Hot Moments and Hot Spots: Identifying Factors Explaining Temporal and Spatial Variation in Turtle Road Mortality". The Journal of Wildlife Management 76.5 (2012): 1047-1052.

29. Nyhus Philip J. "Human-Wildlife Conflict and Coexistence". Annual Review of Environment and Resources 41.1 (2016): 143171.

30. Fernandes-Ferreira Hugo., et al. "Hunting of Herpetofauna in Montane, Coastal, and Drylands Areas of Northeastern Brazil". Herpetological Conservation and Biology 8.3 (2013): 652-666.

31. Schulze C., et al. "Electrical Injuries in Animals: Causes, Pathogenesis, and Morphological Findings". Veterinary Pathology 53.5 (2016): 1018-1029.

\section{Volume 3 Issue 10 October 2021 (C) All rights are reserved by Roberta da Rocha Braga and Antônio Rafael Lima Ramos.}

